\title{
A Systemic Administration of NMDA Induces Immediate Early Gene pip92 in the Hippocampus
}

\author{
*Kwang Chul Chung, $\dagger \neq$ Song Woo Shin, $†$ Min Yoo, $\ddagger$ Min Young Lee, §Hyun Woo Lee, \\ $\ddagger$ Byung Kil Choe, and *Young Soo Ahn
}

*Department of Pharmacology and Brain Research Institute, Yonsei University College of Medicine, Seoul; $\dagger$ Department of Biology, College of Natural Science, Keimyung University, Taegu; $\$$ Institute for Medical Science, Kosin University College of Medicine, Pusan; and §Department of Chemistry, College of Natural Science, Inha University, Inchon, Korea

\begin{abstract}
In the mammalian CNS, aspartate and glutamate are major excitatory amino acids, and their receptors are believed to mediate a wide range of physiological and pathological processes, including neurotransmission, plasticity, excitotoxicity, and various forms of neurodegeneration. The immediate early gene pip92 has been identified in serum-stimulated BALB/c 3T3 fibroblasts, activated $\mathrm{T}$ lymphocytes treated with cycloheximide, and fibroblast growth factor-stimulated hippocampal cells during neuronal differentiation. In this study we have demonstrated that pip92 is expressed in the mouse brain after a single intraperitoneal injection of NMDA. The distribution of pip92 mRNA levels in the NMDA-treated mouse brain was investigated using in situ RT-PCR. The region-specific activation of pip92 in the CNS was observed $3 \mathrm{~h}$ after NMDA injection, and high levels of pip92 mRNA were detected in the hippocampal dentate gyrus and piriform cortex regions. In addition, the activation of pip92 by NMDA was mediated by activation of mitogenactivated protein kinases (MAPKs), such as c-Jun Nterminal kinase (JNK) and p38 kinase, but not extracellular signal-regulated kinase (ERK) in the mouse hippocampus and immortalized rat hippocampal progenitor cells. This study suggests that pip92 is likely to play an important role in neuronal cell death induced by excitotoxic NMDA injury in the CNS. Key Words: NMDA - pip92Excitotoxic injury-c-Jun N-terminal kinase-p38-Hippocampus.

J. Neurochem. 75, 9-17 (2000).
\end{abstract}

In many cell types, extracellular stimuli such as serum, growth factors, phorbol esters, neurotransmitters, cytokines, $\mathrm{Ca}^{2+}$, UV light, and cellular redox agents regulate critical cellular events such as growth, differentiation, and apoptosis through activation of protein kinase cascades. In the brain, excitatory neurotransmission elevates the calcium concentration in neuronal cells and activates the transcription of immediate early genes (Ghosh and Greenberg, 1995). Glutamate and aspartate, the major excitatory neurotransmitters in the brain, become toxic to the CNS via excess activation of ionotropic receptors sensitive to NMDA, kainate, or $\alpha$-amino-3-hydroxy-5methyl-4-isoxazolepropionic acid (AMPA) (Choi et al., 1987). Cell death induced by glutamate is believed to be involved in neuronal loss associated with both acute, e.g., stroke, and chronic, e.g., Alzheimer's disease, neurodegenerative insults (Rothman, 1984; Choi and Rothman, 1990).

The mitogen-activated protein kinase (MAPK) cascade is considered to be a major signaling pathway that links signals from the cell surface to the nuclear events (Hill and Treisman, 1995). This signaling pathway involves transient formation of Ras-GTP, activation of Raf kinases at the membrane, and sequential activation of MAPK kinase (MEK) and MAPK/extracellular signalregulated kinase (ERK) (Marshall, 1994). Activated ERKs translocate to the nucleus, phosphorylate, and thus activate transcription factors such as cyclic AMP response element binding protein and Elk1, resulting in the induction of new gene transcripts. In addition, other

Received September 23, 1999; revised manuscript received January 10, 2000; accepted March 2, 2000.

Address correspondence and reprint requests to Dr. K. C. Chung at Department of Pharmacology, Yonsei University College of Medicine, Shinchon-Dong 134, Seodaemun-Gu, Seoul 120-752, Korea. E-mail: kchung@yumc.yonsei.ac.kr

The current address of S. W. Shin is Department of Anatomy and Neurobiology, University of Maryland, Baltimore, MD, U.S.A.

The current address of $\mathrm{H}$. W. Lee is Department of Environmental Plant System, Oriental Chemical Industries Group Research Center, Inchon, Korea.

Abbreviations used: ACPT-II, $(1 R, 3 R, 4 S)-1$-aminocyclopentane1,3,4-trichlorocarboxylic acid; AMPA, $\alpha$-amino-3-hydroxy-5-methyl4-isoxazolepropionic acid; ERK, extracellular signal-regulated kinase; G3PDH, glyceraldehyde-3-phosphate dehydrogenase; GST, glutathione $S$-transferase; JNK, c-Jun N-terminal kinase; MAPK, mitogenactivated protein kinase; MAPKAP, mitogen-activated protein kinaseactivated protein; MEK, mitogen-activated protein kinase kinase; MEKK, mitogen-activated protein kinase kinase kinase; M-MLV, Moloney murine leukemia virus; MTT, 3-(4,5-dimethylthiazol-2-yl)2,5-diphenyltetrazolium bromide; NBQX, 6-nitro-7-sulfamoylbenzo[ $f$ ]quinoxaline-2,3-dione; SEK1, stress-activated protein/extracellular signal-regulated kinase kinase 1; SRE, serum response element; SRF, serum response factor; TCF, ternary complex factor. 
members of the MAPK superfamily-c-Jun N-terminal kinase (JNK) and p38 - are activated by inflammatory cytokines and cellular stresses such as UV and high osmolarity (Kyriakis et al., 1994; Matsuda et al., 1995).

The immediate early gene pip92 (also known as chxl or ETR101) is rapidly and transiently induced by serum, platelet-derived growth factor, nerve growth factor, fibroblast growth factor, and 12-O-tetradecanoylphorbol 13 -acetate and is functionally implicated in the neuronal differentiation process (Charles et al., 1990; Chung et al., 1998). pip92 encodes a short-lived, proline-rich protein with no significant sequence similarity to any known protein. However, little is known about the function of its encoded protein. The serum response element (SRE) is the major regulatory element located in the pip92 promoter, which is recognized by serum response factor (SRF) and ternary complex factor (TCF), a family of Ets-domain transcription factors (Latinkic and Lau, 1994). Elk-1 is a member of the TCF family, which is phosphorylated by ERK and therefore activated to form a ternary complex with SRF and SRE (Hill and Treisman, 1995; Treisman, 1995). Electrophoretic mobility shift analysis has demonstrated that Elk-1 binds to Ets sites in the pip92 promoter (Latinkic and Lau, 1994). JNK and p38, as well as ERK, could also phosphorylate Elk-1 (Gille et al., 1995; Whitmarsh et al., 1995, 1997; Janknecht and Hunter, 1997). Although there have been several reports about situations in which JNK and/or p38 activation occurs without influencing cell death (Liu et al., 1996; Lenczowski et al., 1997), high levels of JNK and p38 activities have been correlated with the induction of apoptosis in many instances (Raitano et al., 1995; Xia et al., 1995; Chen et al., 1996a,b; Verheij et al., 1996; Xu et al., 1996; Zanke et al., 1996; Goillot et al., 1997; Rodrigues et al., 1997; Yang et al., 1997).

Based on these findings, it is possible that JNK and p38 are involved in pip92 induction during the cell death process. However, little is known about its role and the induction mechanism of pip92 in neuronal cell death induced by cytotoxic stress or neurodegenerative insults. To investigate the role of pip 92 in the cellular response to extracellular cytotoxic stimuli, we have tested the effect of a systemic administration of NMDA on pip92 expression in mouse brain and analyzed the possible signaling pathways involved. Here we report for the first time that pip 92 mRNA levels are increased in a region-specific manner in mouse CNS after a single intraperitoneal NMDA injection. Our results indicate that the activation of $\mathrm{p} 38$ and JNK, but not ERK, is involved in the induction of pip92 during NMDA-mediated neuronal cell death, suggesting that different MAPK pathways are involved in expression of the immediate early gene pip92 induced by growth factors and excitotoxic stimuli.

\section{EXPERIMENTAL PROCEDURES}

\section{Materials}

Fetal bovine serum, Dulbecco's modified Eagle's medium, and geneticin were purchased from Life Technologies (Grand
Island, NY, U.S.A.). PD98059 and SB203580 were purchased from Calbiochem (La Jolla, CA, U.S.A.). (+)-MK-801 maleate, 6-nitro-7-sulfamoylbenzo[ $f]$ quinoxaline-2,3-dione (NBQX), and $(1 R, 3 R, 4 S)$-1-aminocyclopentane-1,3,4-trichlorocarboxylic acid (ACPT-II) were purchased from Tocris (Bristol, U.K.). NMDA and all other chemicals were purchased from Sigma (St. Louis, MO, U.S.A.). Dominant-negative MEKK (MEK kinase) and SEK1 (stress-activated protein/ERK kinase 1) mutant, $p \Delta$ MEKK $\left(3^{\prime}\right)$ KR-5'EE-CMV, pSEK1(AL)/EE-CMV, and pEE-CMV DNAs were kindly provided by D. Templeton. Plasmid expressing glutathione $S$-transferase (GST)-MAPKactivated protein (MAPKAP) kinase-2 was obtained from C. K. Huang. Plasmid expressing GST-c-Jun was provided by P. Angel.

\section{Specimen preparation}

Adult ICR mice (weighing 30-35 g) were injected intraperitoneally with $70 \mathrm{mg} / \mathrm{kg}$ NMDA prepared in phosphate-buffered saline (pH 7.4) and killed $3 \mathrm{~h}$ after treatments as described elsewhere (Shin et al., 1998). As a control, an equal volume of vehicle was injected into the mice. The mice were perfused with phosphate-buffered saline through the heart. Then the whole brain was removed to prepare for the molecular biological and histological investigations. The protocols for animal experimentation were approved by the Committee on Animal Care and Experimentation at Kosin University College of Medicine. The general molecular biological methods, such as nucleic acid extraction, RT-PCR, and cloning, were performed as described elsewhere (Ausubel et al., 1995).

\section{Oligonucleotide primers}

Based on the sequences of mouse pip 92 cDNA (Charles et al., 1990) and glyceraldehyde-3-phosphate dehydrogenase (G3PDH) cDNA (Sabath et al., 1990), two sets of oligonucleotide primers (5'-CTACTCTCGTCGAACAAGCATGGAAG3', 5'-GCCACCAGAGCTCTCAGAAGGCCACC-3' for pip 92 ; 5'-GCCACCCAGAAGACTGTGGATGGC-3', 5'-CATGTAGGCCATGAGGTCCACCAC-3' for G3DPH) were synthesized (Bioneer, Korea).

\section{Cell culture and transfection}

Rat neuronal hippocampal progenitor H19-7 cells were generated by transduction with the retroviral vectors containing temperature-sensitive SV40 large T antigen that is functionally active at $33^{\circ} \mathrm{C}$ and inactive at $39^{\circ} \mathrm{C}$ (Eves et al., 1992). The H19-7 cells were grown in Dulbecco's modified Eagle's medium containing $10 \%$ fetal bovine serum and maintained at $33^{\circ} \mathrm{C}$ under $200 \mu \mathrm{g} / \mathrm{ml} \mathrm{G} 418$ selection. Transient transfections were performed using LipofectAMINE reagents (GibcoBRL) according to the manufacturer's protocol. Plasmid pCMVGAL, which contains the Escherichia coli $\beta$-galactosidase gene driven by the cytomegalovirus promoter, was used as an internal control to determine transfection efficiency. When specified, cells were pretreated with $50 \mu M$ noncompetitive NMDA antagonist [(+)-MK-801], $30 \mu M$ selective AMPA/kainate antagonist (NBQX), $100 \mu M$ competitive antagonist of the metabotropic glutamate receptor (ACPT-II), $50 \mu M$ synthetic p38 kinase inhibitor (SB203580), or $30 \mu M$ MEK inhibitor (PD98059) 30 min before NMDA stimulation.

\section{RNA preparations and northern blot analysis}

Total cellular RNAs from H19-7 cells were isolated by the single-step extraction procedure using guanidinium isothiocyanate as described elsewhere (Chomczynski and Sacchi, 1987). 
Northern blot analysis to measure pip92 mRNA levels was done as described previously (Chung et al., 1998).

\section{Assessment of cell survival by 3-(4,5- dimethylthiazol-2-yl)-2,5-diphenyltetrazolium bromide (MTT) extraction assay}

Cell survival was quantified by a tetrazolium salt-extraction method as described elsewhere (Hansen et al., 1989). To each well containing $250 \mu \mathrm{l}$ of medium in a 24 -well plate, $62.5 \mu \mathrm{l}$ of the $5 \mathrm{mg} / \mathrm{ml}$ stock solution of MTT was added. After $2 \mathrm{~h}$ of incubation at $37^{\circ} \mathrm{C}, 250 \mu \mathrm{l}$ of extraction buffer containing $20 \%$ sodium dodecyl sulfate and $50 \% \mathrm{~N}, \mathrm{~N}$-dimethyl formamide $(\mathrm{pH}$ 7.4) was added. After an overnight incubation at $37^{\circ} \mathrm{C}$, the optical density at $570 \mathrm{~nm}$ was measured using a Spectra MAX 340 ELISA Reader (Molecular Devices, Sunnyvale, CA, U.S.A.), using the extraction buffer as the blank.

\section{In vitro $R T-P C R$}

Total RNA was prepared from the brain using RNAzol B solution (BIOTEX). The RT conditions were as follows: $4 \mu \mathrm{g}$ of total RNA, $4 \mu \mathrm{l}$ of Moloney murine leukemia virus (MMLV) $5 \times$ RT buffer, $4 \mu$ l of $10 \mathrm{~m} M$ deoxynucleotide triphosphates, 100 pmol of oligo(dT) $)_{16}, 20$ units of RNasin, 100 units of M-MLV reverse transcriptase, and RNase-free water to a total volume of $20 \mu \mathrm{l}$. The RT mixture was incubated for $1 \mathrm{~h}$ at $42^{\circ} \mathrm{C}$. The PCR conditions were as follows: $1 \mu \mathrm{l}$ of RT products, $3 \mu \mathrm{l}$ of Taq $10 \times$ buffer, $1 \mu \mathrm{l}$ of $10 \mathrm{~m} M$ deoxynucleotide triphosphates, $10 \mathrm{pmol}$ of sense and antisense primer, 1 unit of Taq polymerase, and deionized water to a total volume of $30 \mu \mathrm{l}$. PCR amplification ( 30 cycles) was carried out at $94^{\circ} \mathrm{C}$ for $30 \mathrm{~s}, 65^{\circ} \mathrm{C}$ for $30 \mathrm{~s}$, and $72^{\circ} \mathrm{C}$ for $30 \mathrm{~s}$.

\section{In situ RT-PCR}

Mouse brains were cryosectioned $10 \mu \mathrm{m}$ thick and mounted on 3-aminopropyltriethoxysilane-coated slides. Slides were fixed in $4 \%$ paraformaldehyde, washed in phosphate-buffered saline, and dehydrated in serial concentrations of ethanol. Genomic DNA was removed using RNase-free DNase (8 U/100 $\mu$ l). In situ RT mix contained $5 \mu$ of M-MLV $5 \times$ RT buffer, $5 \mu$ of $10 \mathrm{~m} M$ deoxynucleotide triphosphates, 100 pmol of oligo $(\mathrm{dT})_{16}, 20$ units of RNasin, 100 units of M-MLV reverse transcriptase, and RNase-free water to a total volume of $25 \mu \mathrm{l}$. The section was washed with distilled water and dehydrated with $100 \%$ ethanol. The slide seal for in situ PCR (TaKaRa, Japan) was located around the tissue section on the slide and covered with PCR mixture. In situ PCR mix contained $2.5 \mu \mathrm{l}$ of Taq $10 \times$ buffer, $2.5 \mu \mathrm{l}$ of $10 \times$ PCR dig-labeling mix (Boehringer Mannheim), $25 \mathrm{pmol}$ of sense and antisense primers, 2.5 units of Taq polymerase, and deionized water to a total volume of $25 \mu \mathrm{l}$. Cycling conditions were the same as in vitro PCR conditions. The in situ PCR amplification was carried out in an OmniGene thermocycler (Hybaid, U.K.), and the products were visualized using the digoxigenin detection kit (Boehringer Mannheim). Slides were analyzed using an optical microscope. Positive-staining cells were purple, whereas negative cells usually appeared colorless or slightly brown.

\section{Protein kinase assay for ERK, JNK, and p38}

Dissected tissues were homogenized using buffer A containing $20 \mathrm{~m} M$ Tris ( $\mathrm{pH} 7.9$ ), $137 \mathrm{~m} M \mathrm{NaCl}, 5 \mathrm{~m} M \mathrm{Na}_{2}$ EDTA, $10 \%$ glycerol, $1.0 \%$ Triton X-100, $0.2 \mathrm{~m} M$ phenylmethylsulfonyl fluoride, $1 \mu \mathrm{g} / \mathrm{ml}$ aprotinin, $20 \mu M$ leupeptin, $1 \mathrm{~m} M$ $\mathrm{Na}_{3} \mathrm{VO}_{4}, 1 \mathrm{~m} M$ EGTA, $10 \mathrm{~m} M \mathrm{NaF}, 1 \mathrm{~m} M$ tetrasodium pyrophosphate, and $1 \mathrm{~m} M \beta$-glycerophosphate. Confluent cells were harvested and lysed using the same buffer. Cell lysates were subjected to centrifugation at $12,000 \mathrm{~g}$ for $10 \mathrm{~min}$ at $4^{\circ} \mathrm{C}$. Soluble fraction was incubated for $1 \mathrm{~h}$ at $4^{\circ} \mathrm{C}$ with antibodies against JNK1, ERK2, or p38. Immunocomplex kinase assays were performed as described previously (Chung et al., 1999). The phosphorylated substrates were visualized by autoradiography. Myelin basic protein (Santa Cruz Biotechnology, Santa Cruz, CA, U.S.A.), GST-c-Jun (kindly provided by Dr. P. Angel), and GST-MAPKAP kinase-2 (kindly provided by Dr. C. K. Huang) were used as the substrate for ERK, JNK, and p38 kinase, respectively. Bacterial GST-fusion proteins were prepared with the GST purification module (Pharmacia) according to the manufacturer's protocol.

\section{Western blot analysis with anti-ERK, JNK, or p38 antibody}

Western blot analysis was performed by using anti-ERK (Promega, Madison, WI, U.S.A.), anti-JNK (Promega), or antip38 antibody (Santa Cruz), as described previously (Chung et al., 1999). The MAPK bands were visualized by enhanced chemiluminescence (Amersham, U.K.).

\section{RESULTS}

\section{Single intraperitoneal injection of NMDA induced an immediate early gene, pip92, in mouse brain}

In rats, systemic administration of NMDA was commonly used to induce epileptic seizures and excitotoxic CNS injury (Feigenbaum et al., 1989; Nitsch and Frotscher, 1992; Metsis et al., 1993; Bing et al., 1997). In this study we used a single intraperitoneal injection of convulsive-dosage NMDA to induce excitotoxic injury in the mouse brain. We have observed that injection of the same dosage of NMDA induced severe neuronal cell death in the entire hippocampal region of the CNS (data not shown). In addition, apoptosis was observed up to 40 days after NMDA injection, and the expression of a few genes, for example, the immediate early gene c-fos and c-jun and the apoptosis-related gene Fas/Fas ligand (FasL), was observed in the hippocampal area (Shin et al., 1998). To determine the NMDA-induced expression of pip92 transcripts in the CNS, total RNAs from the whole brain were prepared at the indicated time after NMDA injection, and the occurrence of those transcripts

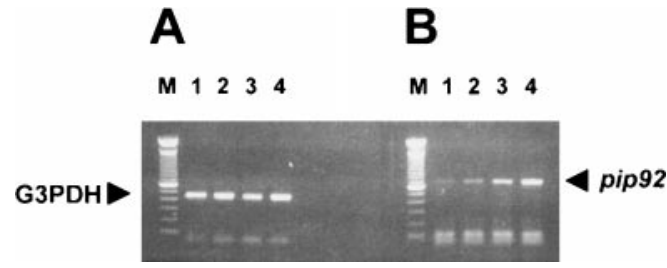

FIG. 1. Induction of mouse brain pip92 mRNA after treatment with NMDA. After a single intraperitoneal NMDA injection (70 $\mathrm{mg} / \mathrm{kg}$ ), mice were killed at the indicated time, and the total brain RNAs were extracted. RT-PCR was performed using specific primer sets of mouse G3PDH as a control for equal RNA loading (A) and pip92 cDNA (B). Lanes 1, 2, 3, and 4 represent control, $1 \mathrm{~h}, 2 \mathrm{~h}$, and $3 \mathrm{~h}$ after NMDA treatment, respectively. Lane M represents the 100-bp DNA ladder size marker (Gibco/BRL). These results are representative of two independent experiments. 
was measured by RT-PCR. As shown in Fig. 1, a single systemic administration of $70 \mathrm{mg} / \mathrm{kg}$ NMDA induced pip92 gene transcripts in the CNS, and their levels increased in a time-dependent manner for up to $3 \mathrm{~h}$ after addition of NMDA.

\section{Region-specific pip92 induction by NMDA in mouse CNS}

The distribution of pip92 mRNA levels in the NMDAtreated mouse brain was investigated using in situ RTPCR. The region-specific activation of pip92 in the CNS is shown at $3 \mathrm{~h}$ after NMDA injection in Fig. 2. Densely labeled pip 92 messages in the hippocampal dentate gyrus and moderate signals in the piriform cortex were detected in the NMDA-treated mice (Fig. 2B). Microscopy with increasing magnification revealed discrete cellular levels of pip92 labeling in each area. However, the corresponding brain section of a control mouse did not show any significant in situ pip92 signal (Fig. 2A).

\section{NMDA induced activation of stress-activated MAPKs, such as JNK and p38, but not ERK in mouse hippocampus}

To clarify the downstream signaling cascades for the induction of pip92 in the mouse hippocampus in response to NMDA, we isolated hippocampal tissue from the brain after a single intraperitoneal injection of 70 $\mathrm{mg} / \mathrm{kg}$ NMDA. Using whole-cell lysates from the hippocampus, we measured the activation of endogenous ERK, JNK, and $\mathrm{p} 38$ by NMDA. As shown in Fig. 3, both JNK and p38 activities increased from $30 \mathrm{~min}$ to $2 \mathrm{~h}$ post-NMDA stimulation. However, we did not detect any significant levels of ERK activation by NMDA. As a control for protein loading, we measured the amount of nonactivated MAPKs by western blot analysis. In all samples, ERK, JNK, and p38 kinase were present at the same levels, respectively (data not shown).

\section{JNK- and/or p38-dependent pip92 induction by NMDA in conditionally immortalized rat hippocampal H19-7 cells}

To confirm the selective activation of p38 and JNK during the excitotoxic NMDA injury, we tested the effect of blocking MAPK signaling pathways on NMDA-induced cell death and pip92 induction in neuronal H19-7 cells. The H19-7 cells are derived from embryonic day 17 rat hippocampal cells that have been conditionally immortalized with temperature-sensitive SV40 large T antigen (Eves et al., 1992). The chemical inhibitors PD98059 and SB203580, which can selectively inhibit the activation of MEK and p38 kinase, respectively, and
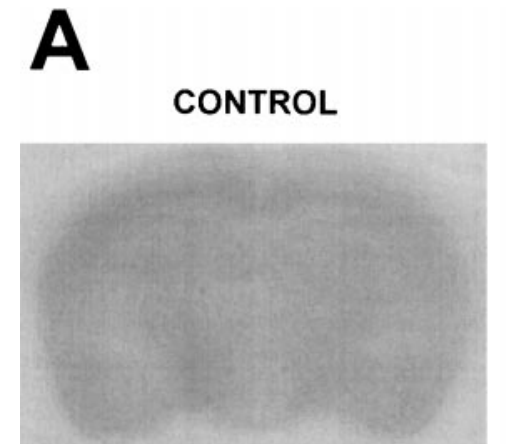

B

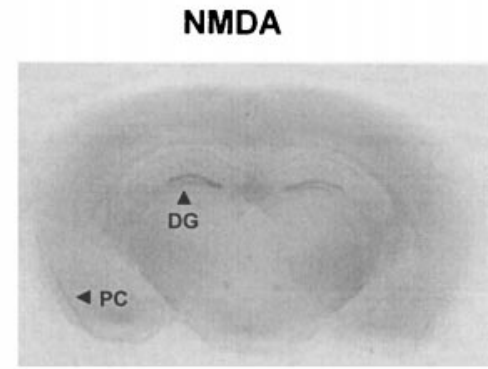

Whole Brain Section

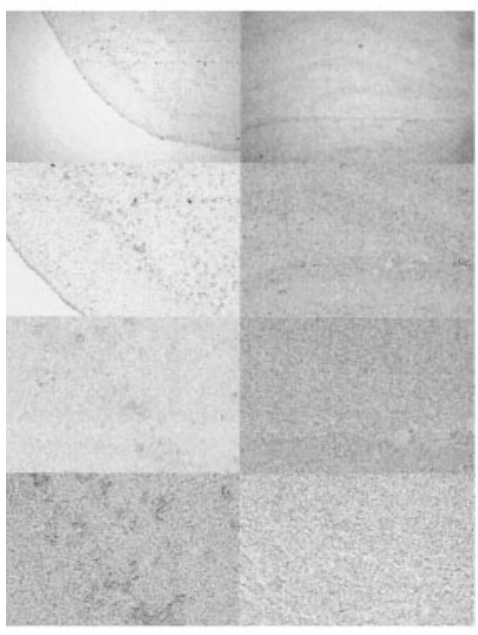

PC

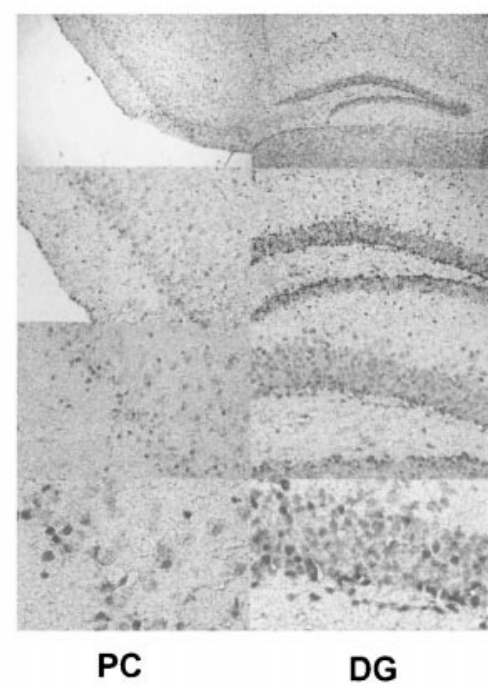

FIG. 2. Localization of pip92 mRNA in mouse brain after a single intraperitoneal injection of NMDA. At $3 \mathrm{~h}$ after a single intraperitoneal injection of (B) NMDA $(70 \mathrm{mg} / \mathrm{kg})$ or $(\mathbf{A})$ vehicle, mice were killed, and brain sections were prepared and followed by immunodetection of dig-dUTPincorporated and amplified pip92 cDNA. Top left panel: Gross structure of brain section in a vehicle-injected or vehicle-treated control mouse after $3 \mathrm{~h}$ (A). Top right panel: Gross structure at $3 \mathrm{~h}$ after NMDA treatment (B). Bottom left and right panels: Micrographs are arranged with increasing order of magnification of enlarged structures of the piriform cortex region (PC; left) and hippocampal dentate gyrus region (DG; right) of (A) vehicle-treated control or (B) NMDA-treated mice, respectively. These results are representative of two independent experiments. 


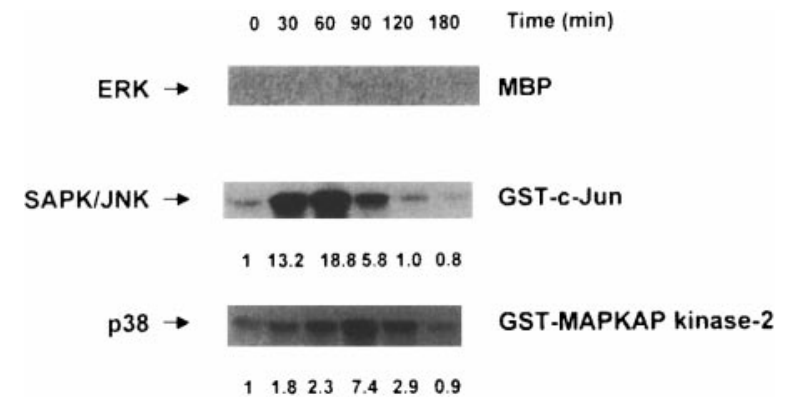

FIG. 3. Effect of a single intraperitoneal injection of NMDA on activation of MAPKs in mouse hippocampus. After a single intraperitoneal NMDA injection $(70 \mathrm{mg} / \mathrm{kg})$, mice were killed at the indicated time, and their hippocampal tissues were dissected. Total cell lysates were prepared, and the protein kinase activities of ERK, stress-activated protein kinase (SAPK)/JNK, and p38 kinase were measured by immunoprecipitation using anti-ERK, anti-JNK1, and anti-p38 antibody followed by an in vitro solid-phase kinase assay. Myelin basic protein (MBP), GST-C-Jun, and GST-MAPKAP kinase-2 were used as ERK, JNK, and p38 substrates, respectively. The numbers at the bottom of the SAPK/JNK and p38 panels indicate quantitated values of fold induction measured using a densitometer. These results are representative of two independent experiments.

kinase-inactive dominant-negative mutant cDNAs in the JNK signaling cascades, such as SEK1 and MEKK, were used. We have examined the effect of NMDA on the viability of H19-7 cells. We observed that treatment of the H19-7 cells with $100 \mu M$ NMDA for $12 \mathrm{~h}$ induced $\sim 75 \%$ cell death, as measured by the MTT extraction assay (Table 1). In accordance with the pattern of hippocampal tissue isolated after a systemic NMDA administration, the same pattern of selective activation of JNK and p38, but not ERK, was observed by $100 \mu M$ NMDA treatments in the H19-7 cells (data not shown). When 50

TABLE 1. Effect of inhibition of the MAPKS ERK, JNK, and $p 38$ on NMDA-induced neuronal cell death in immortalized hippocampal H19-7 cells

\begin{tabular}{lc}
\hline \multicolumn{1}{c}{ Treatment } & Cell survival (\%) \\
\hline No treatment & 100 \\
NMDA & $24.4 \pm 3.6$ \\
SB203580 & $91.2 \pm 5.7$ \\
PD98059 & $93.2 \pm 7.1$ \\
NMDA + SB203580 & $58.7 \pm 8.6$ \\
NMDA + PD98059 & $26.6 \pm 5.2$ \\
NMDA + pCMV & $27.8 \pm 3.9$ \\
NMDA + mut. MEKK & $47.5 \pm 4.1$ \\
NMDA + mut. SEK1 & $53.4 \pm 6.8$ \\
\hline
\end{tabular}

After addition of $50 \mu M$ p38 kinase inhibitor (SB203580) or $30 \mu M$ MEK inhibitor (PD98059) to the H19-7 cells for $30 \mathrm{~min}, 100 \mu M$ NMDA was added and incubated for $12 \mathrm{~h}$. To test the effect of kinase-inactive SEK1 and MEKK mutants on NMDA-induced cell death, $5 \mu \mathrm{g}$ of pEE-CMV (pCMV), p $\triangle$ MEKK $\left(3^{\prime}\right)$ KR-5'EE-CMV (mut. MEKK), or pSEK1(AL)/EE-CMV (mut. SEK1) DNAs was transiently transfected into the cells for $24 \mathrm{~h}$ using LipofectAMINE, followed by addition of $100 \mu M$ NMDA for $12 \mathrm{~h}$. Cell viability was measured by MTT extraction. Results are mean \pm range of data from three independent experiments done in triplicate. $\mu M$ SB203580 (a p38 kinase inhibitor) was added to the cells, we observed a complete inhibition of endogenous p38 activities induced by NMDA (data not shown). As well, addition of $30 \mu M$ MEK inhibitor, PD98059, to the H19-7 cells was shown to block the basic fibroblast growth factor-induced activation of ERK completely, resulting from the inhibition of MEK activity (Kuo et al., 1997)

Pretreatment of H19-7 cells with $50 \mu M$ SB203580 resulted in a significant protection from NMDA-induced cell death (Table 1). However, when $30 \mu M$ PD98059 was added with NMDA, we did not find any significant inhibition of cell death, compared with that induced by NMDA alone. Addition of the same concentration of MEK and p38 kinase inhibitor alone to the cells did not produce a significant cell death. When we transfected the H19-7 cells with kinase-inactive dominant-negative mutant SEK1 and MEKK, there was a significant decrease of cell death, compared with the cells transfected with the parental control vector alone ( $\mathrm{pEE}-\mathrm{CMV}$ ). These data implied that NMDA-mediated neuronal cell death is mediated at least in part by the activation of JNK and p38 kinase, but not ERK. Consistent with the inhibition pattern of NMDA-induced cell death by blocking JNK and p38 kinase activities, we found that NMDA-induced pip92 expression in H19-7 cells is also regulated by JNK and p38 kinase. Northern blot analysis showed that pip92 mRNA levels are induced highly by $100 \mu M$ NMDA (Fig. 4). Induction of pip 92 mRNAs by NMDA was decreased by pretreatment with SB203580 but not PD98059. In a similar way, transient transfection of kinase-inactive SEK1 and MEKK cDNAs into the H19-7 cells also produced a significant inhibition of pip92 ex-

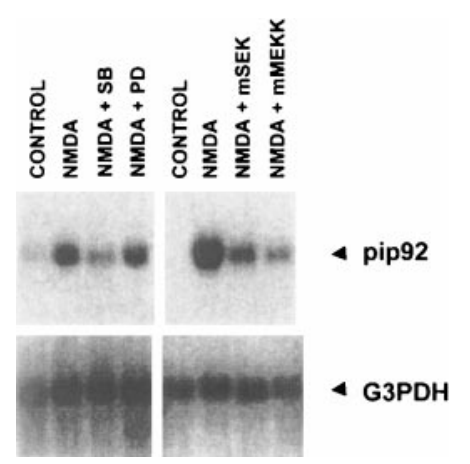

FIG. 4. Effect of the inhibition of the MAPKs, ERK, JNK, and p38 on NMDA-induced pip92 expression in rat embryonic hippocampal neuronal H19-7 cells. After pretreatment of H19-7 cells with $50 \mu M$ p38 kinase inhibitor [SB203580 (NMDA + SB)] or $30 \mu M$ MEK inhibitor [PD98059 (NMDA + PD)] for $30 \mathrm{~min}$ as indicated, $100 \mu M$ NMDA was added and incubated for $3 \mathrm{~h}$. To test the effect of mutant SEK1 (NMDA + mSEK) and MEKK (NMDA + mMEKK) on NMDA-induced pip92 expression, $5 \mu \mathrm{g}$ of the respective mutant DNAs was transfected into the cells, followed by addition of $100 \mu \mathrm{M}$ NMDA for $3 \mathrm{~h}$. Northern blot analysis was performed to measure pip92 mRNA levels. As a control for equal RNA loading, total RNAs were hybridized to ${ }^{32} \mathrm{P}$-labeled G3PDH cDNA probe. These results are representative of three independent experiments. 
pression induced by NMDA, suggesting that p38 and JNK, but not ERK, are involved in the induction of pip 92 during NMDA-mediated neuronal cell death.

\section{NMDA exerts its cytotoxic action through an ionotropic NMDA receptor subtype in hippocampal neuronal H19-7 cells}

To ensure which subtype of glutamate receptors is activated during the induction of immediate early gene pip92 by NMDA in H19-7 cells, we tested the effect of various selective antagonists of glutamate receptor subtypes on NMDA-induced cell death. Various NMDA receptor antagonists, such as the noncompetitive NMDA antagonist (+)-MK-801, the selective AMPA/kainate antagonist NBQX, and the competitive antagonist of the metabotropic glutamate receptor ACPT-II, were used to examine by which receptor subtype the cell death-promoting signals of NMDA are transmitted in the H19-7 cells. When the NMDA-selective MK-801 was pretreated for $30 \mathrm{~min}$, the cell death induced by NMDA was greatly reduced, whereas the AMPA/kainate and the metabotropic glutamate antagonists did not show any significant inhibition of NMDA-induced cytotoxicity (Fig. 5). These data suggest that NMDA exerts its cytotoxic effect via the activation of ionotropic glutamate receptors during the excitotoxic cell death process in neuronal H19-7 cells.

\section{DISCUSSION}

Glutamate receptors have been divided into two major subtypes: ionotropic and metabotropic glutamate receptors. The ionotropic receptors are further categorized into NMDA, AMPA, and kainate receptors based on their agonist names (Watkins et al., 1990). The AMPA/kainate receptors activate ligand-gated cation channels that are permeable to $\mathrm{Na}^{+}$and $\mathrm{K}^{+}$, whereas NMDA receptors are $\sim 10$ times more permeable to $\mathrm{Ca}^{2+}$ than to $\mathrm{Na}^{+}$. In many cases, glutamate neurotoxicity, especially later

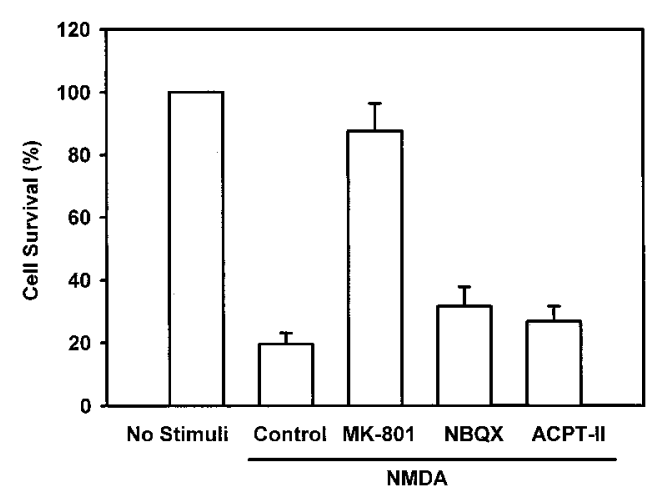

FIG. 5. Effect of various glutamate receptor subtype antagonists on NMDA-induced neuronal cell death in rat hippocampal H19-7 cells. After H19-7 cells were pretreated with (+)-MK-801 (50 $\mu M)$, NBQX $(30 \mu M)$, or ACPT-II $(100 \mu M)$ for $30 \mathrm{~min}, 100 \mu M$ NMDA was added and incubated for $12 \mathrm{~h}$. Cell viability was measured by MTT extraction. Results are mean \pm range (bars) of data from three independent experiments. phases of neuronal degeneration, can be attributed to excessive stimulation of the NMDA subtype of glutamate receptors (Choi et al., 1988; Ankarcrona et al., 1995). Pretreatment with the NMDA receptor antagonist 7-aminophosphonoheptanoic acid reduced acute ischemic hippocampal damage in vivo (Simon et al., 1984). Unilateral injections of NMDA $(25 \mathrm{nmol} / 0.5 \mu \mathrm{l})$ into posterior striatum of 7-day-old rats produced consistent and reproducible lesions characterized by confluent necrosis, gross tissue deformation, and reactive gliosis predominantly affecting the corpus striatum, dorsal hippocampus, and overlying neocortex in the lesioned hemisphere (McDonald et al., 1990). This pattern of damage corresponds to NMDA receptor distributions within the immature brain.

In many studies where the effect of NMDA on the release of neurotransmitters was examined in vivo, the substance was applied to a local region through a probe. This might reflect the fact that it is difficult for NMDA to penetrate into the CNS because of the blood-brain barrier in adult animals. However, several studies have indicated that neonatal rodents are particularly sensitive to systemic administration of excitatory amino acids. Systemic administration of monosodium glutamate to neonatal mice led to acute neuronal necrosis in the developing brain (Olney, 1969). Schoepp et al. (1990) reported that NMDA administered systemically to immature rats caused motor convulsions that were diminished by pretreatment with DL-2-amino-5-phosphonovaleric acid or ( \pm )-3-(2-carboxypiperazin-4-yl)propyl-1phosphonic acid, a competitive antagonist of NMDA receptors. A significant and pronounced increase of the extracellular taurine level in adult rat hippocampal CA1 and striatum was observed after an intraperitoneal injection of $10 \mathrm{mg} / \mathrm{kg}$ NMDA, whereas a similar effect of NMDA was also noted when $300 \mu M$ NMDA was applied locally to both regions via probes (Shibanoki et al., 1993). Systemic applications of kainate and NMDA are known to induce seizure behavior in rats within $90 \mathrm{~min}$, followed by severe neuronal cell death in hilar and pyramidal neurons of the hippocampus within 3 days (Dragunow and Preston, 1995). A single systemic application of a convulsive dose of NMDA to mice also results in both short- and long-term excitotoxic effects on the CNS (Dragunow and Preston, 1995). These findings suggest that NMDA administered systemically acts directly on the specific receptors located in the brain after penetration through the blood-brain barrier, even if such penetration is strongly restricted by the blood-brain barrier system. Brace et al. (1997) have shown that both NMDA and kainate not only damage neurons and myelin but also compromise the integrity of the blood-brain barrier.

The immediate early gene pip 92 (also known as chxl or ETR101) was independently cloned from serum-stimulated BALB/c 3 T3 fibroblasts (Charles et al., 1990) and activated $\mathrm{T}$ lymphocytes treated with cycloheximide (Coleclough et al., 1990). Human pip92 cDNA was cloned from the myeloid leukemia cell line HL-60 (Shimizu et al., 1991). pip92 is rapidly and transiently 
induced by stimulation with serum growth factors and the tumor promoter 12- $O$-tetradecanoylphorbol 13-acetate in fibroblasts and by treatment with nerve growth factor or membrane depolarization in $\mathrm{PC} 12$ cells (Charles et al., 1990). The pip92 promoter has been cloned, and its transcription is induced by serum in mouse 3T3 fibroblasts via the SRE.

The SRE, studied most extensively in the c-fos promoter, consists of a CArG box that binds to the SRF. When SRF is bound to the c-fos SRE, it recruits a TCF to an upstream Ets-like binding site (Hill and Treisman, 1995; Treisman, 1995). In the pip 92 promoter, the SRE consists of at least one Ets protein binding site and a CArG site. Gel shift analysis demonstrated that the Ets sites in the pip92 promoter bind to Elk-1 on phosphorylation of two sites, $\operatorname{Ser}^{383}$ and $\mathrm{Ser}^{389}$, by ERKs (Latinkic and Lau, 1994; Chung et al., 1998). It was shown that, unlike the c-fos SRE, the pip92 SRE can interact independently with Elk-1 without prior formation of the SRF-DNA binary complex (Latinkic and Lau, 1994; Latinkic et al., 1996). Recently it has been shown that Elk-1 is phosphorylated and therefore activated by JNK and p38, as well as ERK (Gille et al., 1995; Whitmarsh et al., 1995, 1997). However, it is unclear whether Elk-1 is involved in pip92 induction by NMDA. Recently we have determined that pip92 is rapidly and transiently expressed by the translational inhibitor anisomycin in NIH 3 T3 fibroblast cells and that its expression is mediated by the JNK- and p38-dependent activation of Elk-1 (K. C. Chung et al., manuscript in preparation). In addition to Elk-1, the other family member of the TCF, Sap-1a, has been reported to be phosphorylated by $\mathrm{p} 38$ and involved in c-fos expression through the SRE in human embryonic kidney 293 cells (Janknecht et al., 1993). It is also possible that Sap-1 and/or other unidentified members of TCF regulate pip 92 expression by NMDA via its SRE. Answers to these questions will enhance our understanding of the mechanism of how mitogenic signals and excitotoxic insults elicit the nuclear response.

pip92 encodes a short-lived, proline-rich protein with no significant sequence similarity with any known protein. However, to date, little is known about the function of its encoded protein. Recently, it has been shown that pip92 is selectively induced by differentiating factors in rat hippocampal neuronal cells, suggesting that it is a key component in neuronal differentiation (Chung et al., 1998). Those studies also reveal the presence of at least two pathways, one MAPK-dependent and the other MAPK-independent, for the induction of pip92 in response to basic fibroblast growth factor or to activated Raf-1 in neuronal H19-7 cells. In addition to differentiation, the present study demonstrates that pip92 is likely to play an important role during the NMDA-induced excitotoxic injury process. The region-specific induction of pip92 in the hippocampus is mediated by activation of the MAPKs JNK and p38, but not ERK, suggesting that different MAPK pathways are involved in pip92 expression induced by growth factors and excitotoxic stimuli. p38 and JNK are known to be involved in cell death induced by nerve growth factor deprivation in PC12 cells, by ceramide in U937 and BAE cells, and by anti-IgM antibody in human B lymphocytes (Xia et al., 1995; Graves et al., 1996; Verheij et al., 1996). In cultured chick fetal forebrain neurons, p38 activity was down-regulated by insulin, which can help these cells survive (Heidenreich and Kummer, 1996). Recently, activation of p38 kinase has been reported in glutamateinduced apoptosis in rat cerebellar granule cells, suggesting an essential role of p38 kinase in mediating the death-promoting activity of glutamate (Kawasaki et al., 1997). In cultured cortical neurons, ERK activity was enhanced by stimulation of metabotropic and kainate types of glutamate receptors but not by stimulation of the NMDA receptor (Fiore et al., 1993). Consistent with this finding, by using three different glutamate receptor subtype antagonists we have determined that the cytotoxic effect of $100 \mu M$ NMDA is mediated by the activation of ionotropic NMDA receptor in the H19-7 cells.

Many actions of NMDA are coupled to the influx of extracellular $\mathrm{Ca}^{2+}$ mediated directly or indirectly by its receptor present in neurons. Transient changes in intracellular $\mathrm{Ca}^{2+}$ levels are known to trigger several cellular responses, including the change of gene expression. We have observed that treatment of H19-7 cells with thapsigargin, which causes $\mathrm{Ca}^{2+}$ to leak out of internal stores and elevates the intracellular $\mathrm{Ca}^{2+}$ levels (K. C. Chung et al., manuscript in preparation), increases the transcription of pip92 in neuronal H19-7 cells.

Acknowledgment: This work was supported by research grant 981-0714-104-2 from the Korea Science and Engineering Foundation, 1998 (to K.C.C.). We thank Dr. M. R. Rosner for support with this project, Drs. S. Ryu, M. G. Lee, and D. G. Kim for insightful comments and generous technical assistance, and Mr. Bob Ross and S. Lee for reading the manuscript critically. We are grateful to Mrs. K. H. Pyun for the preparation of tissue section and to Drs. C. K. Huang for providing GST-MAPKAP kinase-2 expression plasmid, D. Templeton for dominant-negative SEK1 and MEKK, and P. Angel for GST-c-Jun.

\section{REFERENCES}

Ankarcrona M., Dypbukt J. M., Bonfoco E., Zhivotovsky B., Orrenius S., Lipton S. A., and Nicotera P. (1995) Glutamate-induced neuronal death: a succession of necrosis or apoptosis depending on mitochondrial function. Neuron 15, 961-973.

Ausubel F., Brent R., Kingston R. E., Moore D. D., Seidman J. G., Smith J. A., and Struhl K. (1995) Short Protocols in Molecular Biology, 3rd edit. Wiley, New York.

Bing G., Wilson B., Hudson P., Jin L., Feng Z., Zhang W., Bing R., and Hong J. S. (1997) A single dose of kainic acid elevates the levels of enkephalins and activator protein-1 transcription factors in the hippocampus for up to 1 year. Proc. Natl. Acad. Sci. USA 94, 9422-9427.

Brace H., Latimer M., and Winn P. (1997) Neurotoxicity, blood-brain barrier breakdown, demyelination and remyelination associated with NMDA-induced lesions of the rat lateral hypothalamus. Brain Res. Bull. 43, 447-455.

Charles C. H., Simske J. S., O’Brien T. P., and Lau L. F. (1990) Pip92: a short-lived, growth factor-inducible protein in BALB/c $3 \mathrm{~T} 3$ and PC12 cells. Mol. Cell. Biol. 10, 6769-6774. 
Chen Y. R., Meyer C. F., and Tan T. H. (1996a) Persistent activation of c-Jun N-terminal kinase 1 (JNK1) in gamma radiation-induced apoptosis. J. Biol. Chem. 271, 631-634.

Chen Y. R., Wang X., Templeton D., Davis R. J., and Tan T. H. (1996b) The role of c-Jun N-terminal kinase (JNK) in apoptosis induced by ultraviolet $\mathrm{C}$ and gamma radiation. Duration of JNK activation may determine cell death and proliferation. J. Biol. Chem. 271, 31929-31936.

Choi D. W. and Rothman S. M. (1990) The role of glutamate neurotoxicity in hypoxic-ischemic neuronal death. Аnпи. Rev. Neurosci. 13, 171-182.

Choi D. W., Maulucci-Gedde M., and Kriegstein A. R. (1987) Glutamate neurotoxicity in cortical cell culture. J. Neurosci. 7, 357368.

Choi D. W., Koh J. Y., and Peters S. (1988) Pharmacology of glutamate neurotoxicity in cortical cell culture: attenuation by NMDA antagonists. J. Neurosci. 8, 185-196.

Chomczynski P. and Sacchi N. (1987) Single-step method of RNA isolation by acid guanidinium thiocyanate-phenol-chloroform extraction. Anal. Biochem. 162, 156-159.

Chung K. C., Gomes I., Wang D., Lau L. F., and Rosner M. R. (1998) Raf and fibroblast growth factor phosphorylate Elk1 and activate the serum response element of the immediate early gene pip 92 by mitogen-activated protein kinase-independent as well as -dependent signaling pathways. Mol. Cell. Biol. 18, 2272-2281.

Chung K. C., Park J. H., Kim C. H., and Ahn Y. S. (1999) Tumor necrosis factor- $\alpha$ and phorbol 12-myrisate 13-acetate differentially modulate cytotoxic effect of nitric oxide generated by serum deprivation in neuronal PC12 cells. J. Neurochem. 72, 1482-1488.

Coleclough C., Kuhn L., and Lefkovits I. (1990) Regulation of mRNA abundance in activated $\mathrm{T}$ lymphocytes: identification of mRNA species affected by the inhibition of protein synthesis. Proc. Natl. Acad. Sci. USA 87, 1753-1757.

Dragunow M. and Preston K. (1995) The role of inducible transcription factors in apoptotic nerve cell death. Brain Res. Rev. 21, 1-28.

Eves E. M., Tucker M. S., Roback J. D., Downen M., Rosner M. R., and Wainer B. H. (1992) Immortal rat hippocampal cell lines exhibit neuronal and glial lineages and neurotrophin gene expression. Proc. Natl. Acad. Sci. USA 89, 4373-4377.

Feigenbaum J. J., Bergmann F., Richmond S. A., Mechoulam R., Nadler V., Kloog Y., and Sokolovsky M. (1989) Nonpsychotrophic cannabinoid acts as a functional $N$-methyl-D-aspartate receptor blocker. Proc. Natl. Acad. Sci. USA 86, 9584-9587.

Fiore R. S., Murphy T. H., Sanghera J. S., Pelech S. L., and Baraban J. M. (1993) Activation of p42 mitogen-activated protein kinase by glutamate receptor stimulation in rat primary cortical cultures. J. Neurochem. 61, 1626-1633.

Ghosh A. and Greenberg M. E. (1995) Calcium signaling in neurons: molecular mechanisms and cellular consequences. Science $\mathbf{2 6 8}$, 239-247.

Gille H., Strahl T., and Shaw P. E. (1995) Activation of ternary complex factor Elk-1 by stress-activated protein kinases. Curr. Biol. 5, 1191-1200.

Goillot E., Rainguead J., Ranger A., Tepper R. I., Davis R. J., Harlow E., and Sanchez I. (1997) Mitogen-activated protein kinase-mediated Fas apoptotic signaling pathway. Proc. Natl. Acad. Sci. USA 94, 3302-3307.

Graves J. D., Draves K. E., Craxton A., Saklatvala J., Krebs E. G., and Clark E. A. (1996) Involvement of stress-activated protein kinase and p38 mitogen-activated protein kinase in mIgM-induced apoptosis of human B lymphocytes. Proc. Natl. Acad. Sci. USA 93, $13814-13818$.

Hansen M. B., Nielsen S. E., and Berg K. (1989) Re-examination and further development of a precise and rapid dye method for measuring cell growth/cell kill. J. Immunol. Methods 119, 203-210.

Heidenreich K. A. and Kummer J. L. (1996) Inhibition of p38 mitogenactivated protein kinase by insulin in cultured fetal neurons. J. Biol. Chem. 271, 9891-9894.

Hill C. S. and Treisman R. (1995) Transcriptional regulation by extracellular signals: mechanisms and specificity. Cell 80, 199-211.
Janknecht R. and Hunter T. (1997) Convergence of MAP kinase pathways on the ternary complex factor Sap-1a. EMBO J. 16, $1620-1627$.

Janknecht R., Ernst W. H., Pingoud V., and Nordheim A. (1993) Activation of ternary complex factor Elk-1 by MAP kinases. EMBO J. 12, 5097-5104.

Kawasaki H., Morooka T., Shimohama S., Kimura J., Hirano T., Gotoh Y., and Nishida E. (1997) Activation and involvement of p38 mitogen-activated protein kinase in glutamate-induced apoptosis in rat cerebellar granule cells. J. Biol. Chem. 272, $18518-$ 18521.

Kuo W. L., Chung K. C., and Rosner M. R. (1997) Differentiation of central nervous system neuronal cells by fibroblast-derived growth factor requires at least two signaling pathways: roles for Ras and Src. Mol. Cell. Biol. 17, 4633-4643.

Kyriakis J. M., Banerjee P., Nikolakaki E., Dai T., Rubie E. A., Ahmad M. F., Avruch J., and Woodgett J. R. (1994) The stress-activated protein kinase subfamily of c-Jun kinases. Nature 369, 156-160.

Latinkic B. V. and Lau L. F. (1994) Transcriptional activation of the immediate early gene pip 92 by serum growth factors requires both Ets and CArG-like elements. J. Biol. Chem. 269, 2316323170.

Latinkic B. V., Zeremski M., and Lau L. F. (1996) Elk-1 can recruit SRF to form a ternary complex upon the serum response element. Nucleic Acids Res. 24, 1345-1351.

Lenczowski J. M., Dominguez L., Eder A. M., King L. B., Zacharchuk C. M., and Ashwell J. D. (1997) Lack of a role for Jun kinase and AP-1 in Fas-induced apoptosis. Mol. Cell. Biol. 17, 170-181.

Liu Z. G., Hsu H., Goeddel D. V., and Karin M. (1996) Dissection of TNF receptor 1 effector functions: JNK activation is not linked to apoptosis while NF-kappaB activation prevents cell death. Cell 87, 565-576.

Marshall C. J. (1994) MAP kinase kinase kinase, MAP kinase kinase and MAP kinase. Curr. Opin. Genet. Dev. 4, 82-89.

Matsuda S., Kawasaki H., Moriguchi T., Gotoh Y., and Nishida E. (1995) Activation of protein kinase cascades by osmotic shock. J. Biol. Chem. 270, 12781-12786.

McDonald J. W., Silverstein F. S., Cardona D., Hudson C., Chen R., and Johnston M. V. (1990) Systemic administration of MK-801 protects against $N$-methyl-D-aspartate- and quisqualate-mediated neurotoxicity in perinatal rats. Neuroscience 36, 589-599.

Metsis M., Timmusk T., Arenas E., and Persson H. (1993) Differential usage of multiple brain-derived neurotrophic factor promoters in rat brain following neuronal activation. Proc. Natl. Acad. Sci. USA 90, 8802-8806

Nitsch R. and Frotscher M. (1992) Reduction of posttraumatic transneuronal "early gene" activation and dendritic atrophy by the $N$-methyl-D-aspartate receptor antagonist MK-801. Proc. Natl. Acad. Sci. USA 89, 5197-5200.

Olney J. W. (1969) Brain lesions, obesity, and other disturbances in mice treated with monosodium glutamate. Science 164, 719-721.

Raitano A. B., Halpern J. R., Hambuch T. M., and Sawyers C. L. (1995) The Bcr-Abl leukemia oncogene activates Jun kinase and requires Jun for transformation. Proc. Natl. Acad. Sci. USA 92, $11746-11750$.

Rodrigues G. A., Park M., and Schlessinger J. (1997) Activation of the JNK pathway is essential for transformation by the Met oncogene. EMBO J. 16, 2634-2645.

Rothman S. (1984) Synaptic release of excitatory amino acid neurotransmitter mediates anoxic neuronal death. J. Neurosci. 4, 18841891.

Sabath D. E., Broome H. E., and Prystowsky M. B. (1990) Glyceraldehyde-3-phosphate dehydrogenase mRNA is a major interleukin 2-induced transcript in a cloned T-helper lymphocyte. Gene 91, $185-191$.

Schoepp D. D., Gamble A. Y., Salhoff C. R., Johnson B. G., and Ornstein P. L. (1990) Excitatory amino acid-induced convulsions in neonatal rats mediated by distinct receptor subtypes. Eur. J. Pharmacol. 182, 421-427.

Shibanoki S., Kogure M., Sugahara M., and Isikawa K. (1993) Effect of systemic administration of $N$-methyl-D-aspartic acid on extracellular taurine level measured by microdialysis in the 
hippocampal CA1 field and striatum of rats. J. Neurochem. 61, $1698-1704$

Shimizu N., Ohta M., Fujiwara C., Sagara J., Mochizuki N., Oda T., and Utiyama H. (1991) Expression of a novel immediate early gene during 12-O-tetradecanoylphorbol-13-acetate-induced macrophagic differentiation of HL-60 cells. J. Biol. Chem. 266, 12157-12161.

Shin S.-W., Park J.-W., Suh M.-H., Suh S.-I., and Choe B.-K. (1998) Persistent expression of Fas/FasL mRNA in the mouse hippocampus after a single NMDA injection. J. Neurochem. 71, 1773-1776.

Simon R. P., Swan J. H., Griffiths T., and Meldrum B. S. (1984) Blockade of $N$-methyl-D-aspartate receptors may protect against ischemic damage in the brain. Science 226, 850-852.

Treisman R. (1995) Journey to the surface of the cell: Fos regulation and the SRE. EMBO J. 14, 4905-4913.

Verheij M., Bose R., Lin X. H., Yao B., Jarvis W. D., Grant S., Birrer M. J., Szabo E., Zon L. I., and Kyriakis J. M. (1996) Requirement for ceramide-initiated SAPK/JNK signaling in stress-induced apoptosis. Nature 380, 75-79.

Watkins J. C., Krogsgaard-Larsen P., and Honore T. (1990) Structureactivity relationships in the development of excitatory amino acid receptor agonists and competition. Trends Pharmacol. Sci. 11, $25-33$
Whitmarsh A. J., Shore P., Sharrocks A. D., and Davis R. J. (1995) Integration of MAP kinase signal transduction pathways at the serum response element. Science 269, 403-407.

Whitmarsh A. J., Yang S. H., Su M. S. S., Sharrocks A. D., and Davis R. J. (1997) Role of p38 and JNK mitogen-activated protein kinases in the activation of ternary complex factors. Mol. Cell. Biol. 7, 2360-2371.

Xia Z., Dickens M., Raingeaud J., Davis R. J., and Greenberg M. E. (1995) Opposing effects of ERK and JNK-p38 MAP kinases on apoptosis. Science 270, 1326-1331.

Xu X., Heidenreich O., Kitajima I., McGuire K., Li Q., Su B., and Nerenberg M. (1996) Constitutively activated JNK is associated with HTLV-1 mediated tumorigenesis. Oncogene 13, 135142.

Yang X., Khosravi-Far R., Chang H. Y., and Baltimore D. (1997) Daxx, a novel Fas-binding protein that activates JNK and apoptosis. Cell 89, 1067-1076.

Zanke B. W., Boudreau K., Rubie E., Winnett E., Tibbles L. A., Zon L., Kyriakis J. M., Liu F. F., and Woodgett J. R. (1996) The stressactivated protein kinase pathway mediates cell death following injury induced by cis-platinum, UV irradiation or heat. Curr. Biol. 6, 606-613. 